\title{
Scaremongering or Preparedness? Navy Leagues in Canada, 1895-1939
}

\section{Kenneth S. Mackenzie}

\begin{abstract}
Mettant l'accent sur les exemples canadiens et britanniques, ce texte enquêtera au sujet du rôle que jouent les ligues marines nationales dans la formulation des politiques navales de leur pays, tout au long de la période précédant la guerre, mais particulièrement durant la période entre les guerres quand il semblait que la paix pourrait éclater. Les membres-- 'navals' en termes acceptés--étaient-ils sincèrement intéressés par simplement l'état de préparation, ou existait-il des nuances agressives? Peu importe, ont-ils utilisé des techniques d'alarmisme à fin d'avancer leurs objectifs? Finalement, dans quelle mesure peuvent-ils être crédités-ou blâmés-- pour l'état de leur marine au point de déclenchement de la Deuxième Guerre Mondiale?
\end{abstract}

In a letter to the editor of The Globe and Mail published on 19 July 2010, the writer commented on the Canadian government's recent decision to purchase a number of expensive fighter aircraft for the Royal Canadian Air Force. He pointed out that, at "a deeper level," the decision was a statement of what kind of nation "Canada wished to be in the next fifty years" and wondered whether or not this meant that the country would be led increasingly into "U.S. led military interventions in the future."

The issues raised bear a startling resemblance to a Canadian dilemma almost exactly a hundred years earlier when the country was debating the type of naval service - or indeed any - it needed, and the degree to which it owed support to the British Empire for the defences it had provided as Canada flexed its sovereign muscles after Confederation in 1867. From 1895 until the establishment of the Canadian Naval Service on 4 May 1910 there was one group in Canada that took this matter as its own: local branches of the British Navy League. Although intermittently between 1895 and 1914 there were as many as fourteen local branches across the country, only two really took root in Toronto and in Victoria. There, members vigorously and variously argued the 
two options open to Canada: the extent to which Canadians should contribute to the burgeoning cost of the Royal Navy, or the development of their own standalone naval force. Following an interlude for the Great War, this penchant for internal debate would be renewed, even as the Navy League developed a more singular national voice, but oscillating still with changes in leadership.

This paper will investigate the role of Navy League in Canada in the formulation of the country's naval policy, through the pre-war period but particularly in the period between the wars when it appeared peace might really break out abroad. Were the members - "navalists" in the accepted terms genuinely interested in preparedness alone, or were there aggressive undertones? Either way, did they use scaremongering tactics to forward their aims? Finally, to what extent can they be credited - or blamed - for the state of the Royal Canadian Navy at the outbreak of the Second World War?

In the multitude of patriotic organisations that sprang up in the British Empire after 1867 one of the longest lasting was the Navy League. Established in 1895 in London, the movement spread throughout the empire and the rest of the world, perhaps most significantly in Germany in 1898 and the United States four years later. The branches in Toronto and Victoria came into being in 1895 and 1901 respectively, numbers six and fifty-six in the empire.

The British Navy League was established to ensure that Britain retained its supremacy at sea, both naval and mercantile, a reality that was never seriously in doubt until Kaiser Wilhelm II started feeding his naval aspirations in the last half of the last decade of the nineteenth century. As the build up of the imperial German Navy threatened British supremacy, the stridency of the campaign mounted by Navy League members to force the British government to build and to keep building the most modern - and the most expensive warships increased. When in February 1906 Admiral Fisher's HMS Dreadnought, the most formidable warship of its time, was launched, she became the yardstick by which all other navies' capabilities were measured. Thus did "the ruinous naval races that did so much to de-stabilize the world" before 1914 get under way; the ship "became synonymous with all that was wrong with the militarism of that age." "To what extent were navy leagues, and particularly the Navy League in Canada, contributors to the "great naval scares" that developed internationally between 1898 and 1914? Were they contributors to what has been called the "scaremongering" of the times? ${ }^{2}$ This led to a determination of the tactics League members should employ to enable them to get their aims and objectives adopted by their governments. Strangely enough, it

\footnotetext{
1 Angus Ross, "HMS Dreadnought (1906) - a Naval Revolution Misinterpreted or Mishandled?," The Northern Mariner/le marin du nord, XX:2 (April 2010), 176. Not all naval historians agree with Ross's dire pronouncement on the role of navies in causing the First World War. See particularly Andrew Lambert, Admirals: the Naval Commanders Who Made Britain Great (London, 2008), 313.

2 Whose position is put best in A.J.A. Morris, The Scaremongers: the Advocacy of War and Rearmament 1896-1914 (London, 1984).
} 
was a Toronto member who put the question most succinctly. At a meeting there on 21 October 1903, he stated that "the general work of the Navy League may be roughly described as being divided into two parts, namely Agitation and Education."3 While not mutually exclusive, which method would or should dominate or, more importantly, which had the better chance of success with governments and the populace, would shape the discourse of the Navy League in Canada through the coming decades until the eve of the outbreak of the Second World War.

By virtue of its geographical location next to the United States with its Monroe Doctrine, by which other foreign powers were discouraged from intervening in the Americas, Canada was able, if it chose, to remain aloof from the plight of the farthest reaches of the empire, that they faced as a result of their geography. ${ }^{4}$ In turn this became an issue of imperial solidarity - one of the most contentious issues in Canadian polity.

So it was that Canada's earliest sea protection was provided haphazardly by a quasi-military, seasonal force that was slowly enhanced as circumstances demanded. This eventually became known as the Fisheries Protection Service (FPS), and by the time the Toronto branch of the Navy League in Canada came into being, this service's "gradual militarization" had proceeded to the point that it could be discerned as the kernel of a real naval force. ${ }^{5}$ For Canadians squeamish about things military or of the possibility of the country becoming involved in rampaging (British) imperialism, this solution was a satisfactory way to provide just enough coastal defence.

This was the rather comfortable position when the Liberals under Prime Minister Wilfrid Laurier came to power in 1896. They being the most squeamish of Canadian parties concerning imperial adventures, Laurier nevertheless realised that the slow evolution of the FPS was necessary for Canada to protect adequately its sovereignty. The service's incremental advance was in the main acceptable to the members of the then dominant branch of the Navy League, in Toronto. This was particularly so as by 1905 the FPS possessed what could really be classified as minor war vessels. ${ }^{6}$ The branch, led by its long time honorary secretary, H.J. Wickham, was in tune with the Liberal government's approach, showing only the occasional concern at the snail's pace of the enhancement of Canada's sea defence capacity. It also developed peripheral concerns, such as the formation of a naval militia, either for

\footnotetext{
3 As quoted in The Navy League Journal (NLJ), December 1903, 278. This was the official organ of the British Navy League.

${ }^{4}$ On occasion Canadians were wont to point out that the imperial loyalty of Australians and New Zealanders owed as much to their geographical vulnerabilities to their "greater love of Britain," as a Canadian Navy League stalwart put it to a meeting of the Navy League in London on 27 November 1931. After making the point, Frederick Williams Taylor cogently remarked they were simply following "the wise and natural instinct of self-preservation" (The Navy - successor to NLJ - January 1931, 17-18).

${ }^{5}$ Marc Milner, Canada's Navy, the First Century (Toronto, 1999), 13-16.

${ }^{6}$ Milner, Canada's Navy, 11-12.
} 
Canadian purposes or to bolster the Royal Navy, and local shipbuilding and ship owning. Although the League strenuously pointed out its non-political status, the distinction between that and non-partisanship was always evident. ${ }^{7}$ Inevitably, in Toronto, the branch was tied to the Laurier government. This was particularly so for Wickham, who maintained a constant stream of letters to the prime minister and his ministers of Marine \& Fisheries, initially J.R.F Préfontaine until his death in 1905 and thereafter L.P. Brodeur, offering advice as to how Canada's naval policy should develop. ${ }^{8}$

With all things naval appearing to fall into place, and Toronto members of the League satisfied that the government had heeded their various suggestions between 1907 and 1909, they lost interest in matters naval. ${ }^{9}$ By the time the debates on the Naval Service Act commenced in Parliament, the last vestige of their public pronouncements had come to an end. On 4 May 1910 the Act received Royal Assent and, on paper at least, Canada was on the way to possessing its own navy. It had all been achieved without undue scaremongering - at least in Toronto.

This was not quite the case in that remote part of the empire - and Canada - British Columbia. There the Victoria branch members were not as trusting of Laurier's motives. Shortly after the branch's formation in 1901, its members had decided that the only way the West Coast could receive adequate naval protection was to halt the erosion of the Royal Navy presence in the hemisphere, and that could only be achieved by Canada providing a cash contribution to increasingly hard-pressed Britain. ${ }^{10}$ As a result, the branch, at its first annual meeting on 9 May 1902, set in motion a resolution that was passed by the British Columbia legislature on 20 June declaring that "the time has now

\footnotetext{
7 The demarcation line between "politics" and "partisanship" was hotly debated at this time, particularly in the seven years before 1914 when the League's dominant branch, in Victoria, was run by the arch Conservative, Clive Phillipps-Wolley.

8 Effectively, according to Nigel Brodeur's article on his grandfather's time as Minister of Marine \& Fisheries in the Laurier government; Nigel Brodeur, "L P. Brodeur and the Origins of the Royal Canadian Navy," in James A. Boutilier (ed.) RCN in Retrospect, 1910-1968 (Vancouver, 1982), particularly 24. See also the opening chapters of the updated official history, William Johnston, William G. Rawling, Richard H. Gimblett, and John MacFarlane, The Seabound Coast: The Official History of the Royal Canadian Navy, Vol. I, 1867-1939 (Toronto: Dundurn, 2010), passim.

9 J. Castell Hopkins in his The Canadian Annual Review (CAR) 1907, 347, deemed the Toronto Branch by then "mild and ineffective." He should have known, as he was a charter member of the branch and a vigorous navalist. Wickham himself was less pessimistic, dating its somnolence to 1909 in speaking to the Ontario division of the Navy League of Canada on 2 October 1917; Minutes of the Organisation of the Navy League, Ontario Branch, 2 October 1917, copy in possession of the author. At that time Wickham remarked that the Toronto branch had "died out for lack of help" in 1909.

${ }^{10}$ By 1905 the entire Pacific Coast of the American continent had been denuded of all but the most rudimentary of British naval presence. By 1908 the only ships at Esquimalt and Vancouver were two small sloops and the elderly (and in Navy League circles infamous) survey ship HMS Egeria. Paid off in 1910, she had been eagerly sought as a training ship for Vancouver boys with some success (The Victoria Daily Colonist, 17 March 1912), but was not economical to operate.
} 


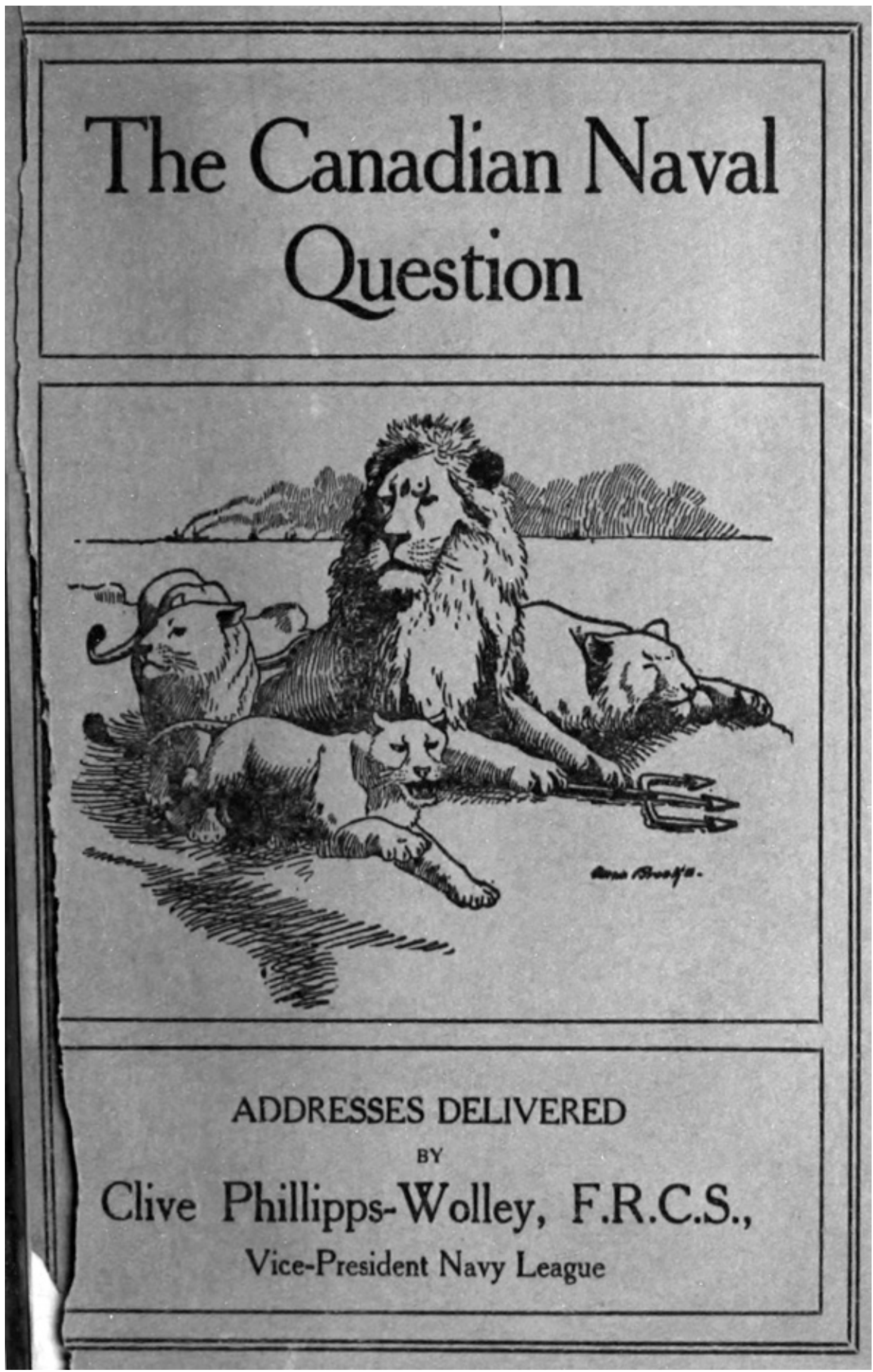

Source: Internet Archive 
arrived when Canada should assume her fair share of the cost of the naval protection afforded" by Britain. ${ }^{11}$

After this first flurry of interest matters waned, and it was not until the election of Clive Phillipps-Wolley as president of the Victoria \& Esquimalt Branch of the Navy League in 1907 that agitation recommenced. Already a controversial figure in British Columbia, ${ }^{12}$ and a staunch Conservative as well as a long-time vice president of the parent League in London, he was far more in the public eye in Victoria than Wickham had ever been in Toronto. If there was any scaremongering done in Canada before 1914, then Wolley was behind it. An example from 1908 is typical. Vancouver had been remarkably reticent in becoming involved in the League, and Wolley convened a combined meeting there of a small number of League adherents and a large number of the ladies of the Imperial Order Daughters of the Empire. ${ }^{13}$ After the opening speaker introduced Wolley with the opinion that "if the occasion arose the people of the Dominion would freely contribute money, men and blood to maintain Britain's supremacy as mistress of the seas," Wolley rose to the occasion. He did not offer hallelujahs, but he thought "the question was of such moment that it might be spoken of in a cathedral by a primate addressing a kneeling people." Canada, he told his listeners, "should build warships and present them to the mother country." The lecture, "heartily enjoyed by a large audience," closed with a singing of patriotic songs. Naval theatre was alive and well in British Columbia. ${ }^{14}$

With the start of the naval debate in Parliament in March 1909 came the news that Canada's partners in the empire, New Zealand and Australia, had stepped up to the plate. Australia determined to change its previous policy of cash contributions to the Royal Navy and build its own fleet unit, whilst smaller New Zealand decided to pay for the construction of a dreadnought and present it to the Royal Navy. This galvanised discussion in Canada as to the way the country should proceed, but whilst the Victoria branch, under Wolley's leadership, vigorously argued its preferred policy, it never conducted an educational programme to convince those interested as to the reasoning behind it. He lost much of his credibility when he allied himself openly with Premier Richard McBride, the arch Conservative BC premier, an avowed exponent of a cash contribution - along with an expensive agenda for achieving better terms for British Columbia under confederation. On 21 April 1909 the two men took to the stage in Victoria to discuss the just announced agreement between the

\footnotetext{
${ }^{11}$ Quoted in CAR, 1902, 145.

12 For Wolley's life, see Patrick Dunae, Gentlemen Emigrants; from the British Public Schools to the Canadian Frontier (Vancouver, 1981). His career with the Navy League in Canada is covered in the author's Keeping Watch: A History of the Navy League of Canada 1895-1965 (Salt Spring Island, BC, 2010).

${ }_{13}$ The ladies of the Imperial Order Daughters of the Empire (IODE) were every bit as patriotic as Canadian men, including the Navy League. There is as yet no history of that worthy organisation.

${ }^{14}$ As reported in the Vancouver Daily Province, 1 December 1908.
} 
federal government and its loyal opposition as to the nature of the upcoming Naval Service Act - the last time a meeting of minds occurred on that topic. The Wolley/McBride orchestrated meeting was a little ambiguous, producing the statement: "That this meeting heartily endorses the policy of defence agreed upon by the two great parties in the Dominion of Canada, but begs those parties to go further and to illustrate the spirit of Canada by an immediate and unconditional gift to the Imperial Navy." While The Colonist was willing to concede that Wolley's position was "quite in line with the position always taken by the Victoria branch of the League," this was stretching the reality somewhat. As the editor of The Times reported, Victoria had "always harbored some individual who hoped to make himself conspicuous by being more loyal than the King or any of his ministers." By inference Wolley was one of these, and the newspaper received several letters criticizing Wolley for his stand. ${ }^{15}$

When the Naval Service Act was passed in the Commons in March 1910, another theatrical meeting was held in Victoria, with "the local navy league... out in force and... a great deal of enthusiasm displayed." As usual The Daily Times had a contrary view, noting, "that there were very few native born people there." After numerous presentations, this newspaper reported, Wolley, "in patriotic frenzy and ...passion," moved a resolution that, while endorsing the government's naval policy, also called upon it to realise there was an emergency that "necessitated an immediate additional contribution of Dreadnoughts, or cash" to the Royal Navy. Wolley carried this message to Vancouver a week later, where another mass meeting passed the same resolution, this time, unlike Victoria, unanimously. ${ }^{16}$

When Wolley conducted an unsuccessful excursion into eastern Canada in the fall of 1910 to try "to infuse life into the dormant Toronto organisation" of the League, ${ }^{17}$ he professed to be slightly more enthusiastic about the Laurier naval policy. Interviewed by a reporter for The Montreal Daily Star, he called it "the best thing for Canada," and stated it was "Canada's Duty to Become (a) Great Naval Power" - as the newspaper's headline put it. All he asked was that the process not take twenty or twenty-five years. ${ }^{18}$ Little was he to know that his pessimistic estimate would not be very far off the mark.

Rebuffed and largely ignored in eastern Canada, Wolley returned to his home province, there to produce a compilation of his addresses. Published under the title of The Canadian Naval Question, it received perhaps as little attention as had his tour. Castell Hopkins described it as being written "in terse,

\footnotetext{
15 Both Victoria newspapers, the Liberal Daily Times, and The Daily Colonist - which should have been called "The Daily Conservative" - had extensive coverage of this event around 22 April 1909. The event was an excellent example of what Jan Rüger described in his provocative book, The Great Naval Game: Britain and Germany in the Age of Empire (Cambridge, 2007).

${ }^{16}$ Vancouver Daily Province, 19 March 1910.

17 CAR, 1910, 128, and 1912, 151.

18 Published in The Montreal Daily Star, 28 October 1910. This is the only newspaper report of Wolley's ventures I have been able to locate in a major eastern Canadian newspaper.
} 
nervous English;" he made up for Wolley's verbosity by describing its message in a few words: "Support the Canadian Navy as an integral part of the British Navy; prepare for an immediate emergency and make strong the basis of Canada's interest in sea power." Neither he nor Wolley explained the hows and whys of achieving these goals, hoping Canadians would trust them. ${ }^{19}$

Canadians and their politicians were then left to attempt to digest the fact that they now possessed a rudimentary naval service. Shortly after this, naval scare sceptics declared "the Dreadnought Scare" as being over, an assessment now endorsed by reputable naval historians. Any controversy over Canada's naval policy could - and should - have been over, and the government to be seen advancing the schemes it had suggested during the debates to bring Canada to a sensible self sufficiency in matters of its naval defence. As The Globe editorialized on 12 November 1910, the time was "opportune for a full and frank discussion of the permanent relations that should exist between Great Britain and Canada in matters of naval defence." ${ }^{\prime 20}$ The time was ripe for an informed and realistic educational campaign on the issue; few if any rose to the challenge, least of all Wolley.

A variety of circumstances militated against Canadians building a sea consciousness at this time; they had much more pressing issues on their mind than developing a navy. When it came time for an election, in September 1911, trade matters, and specifically reciprocity with the United States, dominated the hustings. Naval matters were virtually ignored outside Quebec, perhaps most remarkably by Wolley and what was left of the Navy League in Victoria.

Not until Wolley and McBride teamed again did agitation re-emerge. In Trafalgar Day celebrations on 21 October 1911 another mass meeting was held. Well reported in the local press, the resulting resolution built on the earlier demand for adequate naval protection on the west coast: the government of Canada should "be urged to take such immediate steps as will lead to the creation of a Canadian Fleet unit in the Pacific and the establishment of a naval base and shipbuilding yards at Esquimalt, with such promptitude as to make this Coast ready for... the completion of the Panama Canal." This re-awakening came not a moment too soon; in a critical editorial, the previously supportive Daily Colonist noted that for too long the Navy League had simply "played a sentimental part in the life of Victorians." It was time, with "the re-awakening of Canada to a full sense of her imperial responsibilities," for the country to "now play a practical part" in that process. The editor urged League members to strike while the iron was hot and when "it might reasonably expect to have its counsels considered on such a matter of national and imperial importance., ${ }^{21}$ The League was being urged to scaremonger.

19 CAR, 1910, 180.

${ }^{20}$ See The Globe, 12 November 1910; Lambert, Admirals, 313; and Morris, Scaremongers, extensively.

${ }^{21}$ The Daily Colonist, Victoria, 22 October 1911. Naturally, The Daily Times was not nearly as appreciative. 
The prod worked - to a degree. Over the winter of 1911-12 League members in Victoria and Esquimalt strove to become an influential force. Temporary success was announced at the annual meeting of the branch on 21 March 1912. At that time the members agreed to form a provincial umbrella organisation "for the purpose of adding to the influence of their counsels." Wolley, despite being the branch's president, did not attend this meeting, which was chaired by W.H. Langley, a Liberal, who in the course of the meeting expressed his dismay that "the question of naval defense was being made a political football." At the organisational meeting of the "Federated Navy League of British Columbia" held on 30 July, Wolley was nevertheless elected its president. At this time it was resolved that no Canadian naval policy would "be satisfactory to the people of British Columbia which does not include substantial and prompt Contribution [to the Royal Navy], and the establishment of a Fleet Unit on the Pacific Coast."22 This last requirement was almost certainly the stumbling block to a full agreement and the cause of Langley's remarks about the politicisation of the League in Victoria.

The apparent coming together was most opportune; after due consideration the new prime minister, Robert Borden, let it be known in Parliament on 18 March 1912 that he intended to do away with the existing Naval Service Act and devise a Canadian naval policy of his own. The Federated Navy League thus came into being at the perfect time to have its counsels, if made, count. There turned out to be plenty time for that to happen as, to the consternation and discomfort of navalists, Borden delayed the announcement of his new policy until 5 December, thus presenting the Victorians a golden opportunity to develop their suggestions. Unfortunately the "great naval debate" 23 developed with only marginal input from Wolley and his cohorts.

A main reason is that Borden had added to the problems caused by his long delays in announcing his permanent polity by committing a strategic blunder in addition to the political one acknowledged by his biographer ${ }^{24}-$ he did not include a specific Pacific fleet unit, the ardent hope of navalists in Victoria, in the policy. Borden's Emergency Aid Bill, a temporary scheme to help succour the Royal Navy while awaiting development of a permanent policy, met with Wolley's unconditional approval. This bill, excluding the Pacific fleet unit, destroyed chances of a non-political approach in Victoria and gave welcome ammunition to those there who, whilst in favour of a Canadian navy, were adamantly opposed to cash contributions to Britain.

Borden tried to make up for the delay, writing Wolley a congratulatory letter in advance of his policy announcement, and saying how pleased the Navy

\footnotetext{
${ }^{22}$ The reports are in The Colonist, 22 March 1912 and 1 August 1912. Hopkins listed this in his summary of events in the section of CAR, 1912 on "The Naval Question." W.H. Langley would become a fixture in the Navy League of Canada after the First World War.

${ }^{23}$ R. Craig Brown, Robert Borden, I, 1854-1914 (Toronto, 1975), chapter 11.

${ }^{24}$ Brown, Robert Borden, 235.
} 
League president would be with it. This was read out at yet another mass meeting - the only way in which Navy League affairs received publicity - on 30 October 1912, reigniting the controversy rather than helping Wolley. The Colonist thought it gave proof that the local branch was "the very heart and soul of the Navy League movement in Canada," while The Times mocked the whole process because of "a conspicuous absence of any intention to insist on a fleet unit for the Pacific Coast." Wolley bravely announced that the battle was over, and expressed the fervent hope that, rather than a one-time contribution, Canada would provide regular assistance to Britain for imperial naval defence. ${ }^{25}$ When the Borden naval nolicy made no reference to a Pacific fleet unit, the uneasy truce between League members in Victoria came to an end.

Immediately after Borden's announcement of 5 December, the Colonist canvassed prominent Victorians as to their opinions of it. Wolley and a William Blakemore were queried, as prominent representatives of the League in Victoria. Wolley expressed his unconditional approval of the new policy, and was silent about the lost fleet unit - an issue he would try desperately and unsuccessfully to rationalise over the coming months. Blakemore, on the other hand, deemed the whole policy as "'huckstering" and distasteful. Wolley promptly disagreed with "his very good friend... the Secretary of the British Columbia Navy League" who until then had been "the strongest supporter of the Navy League's policy" ${ }^{26}$ - a policy the League had yet to reveal to its members, let alone the general public.

There the League conflict was held from the public, until "Ultima Thule," writing to The Times on 3 February 1913, posed the question as to who exactly was "that body of strange men who constitute the local branch of the Navy League"? Since the submersion of the fleet unit, its members had "without exception, been as silent as the angel of death." This is not to say that the Victoria public was bereft of reading on the continuing naval debate. Both local newspapers went at it hammer and tongs, and The Times published at least a dozen front-page cartoons making fun of the Borden bill.

It all came to a head in early April 1913. The Colonist finally prevailed upon Wolley to sit for an interview on 3 April, and he had obviously lost all patience with the democratic process. He attacked bitterly the loyal opposition's delaying tactics and "the fog of verbosity... in parliamentary discussion" on the topic, put faith in Borden's claim that there was indeed a naval emergency facing Britain that required imperial solidarity, and then asked Canadians to trust Borden to bring in his permanent naval policy just as soon as he could. The accompanying editorial in the newspaper praised Wolley, stating that "few, if any, more lucid statements" on the naval policy of the country had been

\footnotetext{
${ }^{25}$ Wolley's reaction was half-hearted. He regurgitated sections of The Canadian Naval Question in successive Sundays of The Daily Colonist, 3 November to 1 December 1913. The last column, on "Canada's Naval Policy," did nothing to advance the debate.

${ }^{26}$ The Daily Colonist, 6, 8 December 1912. By this time Wolley had retreated to his rural home at Somenos, north of Victoria.
} 
forthcoming, and that with his "trenchant interview" he had touched "on the mainspring of the question." Trenchant it was, for it also proved the truth of that famous maxim, when in a hole, stop digging. In a disclaimer at the beginning of the report, Wolley had insisted that "anything I say on this subject is said by Mr. Phillipps-Wolley, and not as the president of the Navy League" - and his colleagues ensured that would be the case.

The Liberal Victoria Times had a hey-day with the interview and gleefully reported Wolley's approval of Laurier's naval policy from 1909 until the government changed, and noted that his position now was nothing but "the special pleadings of a political partisan." The Colonist came gamely to Wolley's defence, but it was most unconvincing. Wolley himself wrote a reply attempting to deflect criticism of the missing fleet unit, a patently untenable position. Wolley then withdrew from the public fray and left the battlefield to the two newspapers.

On 22 April 1913, the Victoria \& Esquimalt branch held its annual meeting and the forlorn headline in the following day's Colonist said it all: "After Distinguished Service on Behalf of Empire, Mr. Clive Phillipps-Wolley Surrenders Office in Local Organization." Wolley in his final address suggested ill health as a factor, and the accompanying editorial praised him for having "inaugurated a propaganda on the Western Shores of the Dominion which he has seen spread throughout the whole of Canada," a highly suspect statement. Wolley retained the presidency of the Federated League, which held its meeting the next day. The published list of members for the two organisations showed none shared between them. At the Federated League's meeting, it took a concerted call from members on the floor to squeeze out "a definite presentment as to its (naval) policy." When finally hammered out it was accepted "unanimously," in support of Borden's policy so far as it went, whilst reserving to itself the "right to criticize the permanent policy" promised by Borden, should it be found not to contain provision for other matters which the League has persistently advocated, among them the establishment of a fleet unit on the Pacific Coast and the construction of graving docks. As can be imagined, The Times waxed sarcastic over this. ${ }^{27}$

That year's Trafalgar Day celebrations were distinctly low-key. Wolley did so, not in Victoria but in the obscurity of his hometown of Duncan. The main celebration was held in an even smaller place, Ganges, on Salt Spring Island. The next meeting of the Federated Navy League reported in the press was on 3 February 1914, suitably enough in the new Royal Victoria Theatre. Wolley attended from his sick bed in hospital and some members of the recently formed Naval Volunteers of Victoria attended, as did Premier McBride. It was naval theatre at its best - but the only tangible evidence of advance was in the presence of the volunteers. The mandatory resolution was even less committal

${ }^{27}$ Gleaned from The Colonist and The Daily Times, 4-28 April 1913. The Victoria \& Esquimalt branch held its first post-Wolley meeting in W.H. Langley's house (The Daily Times, 15 May 1913). 
than its predecessors, simply urging Borden "to use every effort to remove immediately Canada's reproach, in that so far she has done nothing to aid" the Royal Navy and imperial naval defence. ${ }^{28}$ This did nothing to further the cause either of the Canadian Naval Service or Borden's naval policy, all of which fell by the wayside. The Toronto Mail and Empire gave the most obvious declaration retrospectively on 19 July 1918: "when, (in 1913) an Emergency Naval Aid Bill was introduced by Sir Robert Borden the activity of a powerful Canadian Navy League would have left no politician an excuse for pretending that his antagonism to the measure was owing to uncertainty as to the state of public opinion on the question.... We should have had a permanent naval policy years ago if we had had a live Navy League. ${ }^{29}$ Canada certainly did not possess an effective navy in 1914, and the League's advocacy had certainly failed; whether or not any activity, whether agitation or education, would have made any difference is a moot point. But the newspaper's editorial was speaking in support of the new Navy League of Canada, and urging people to join it so that the same mistakes would not be repeated.

The period from 1914 until 1919 was but an interlude in the life of Canadian navalists. With Canada having no fighting navy, those League members still active were left largely adrift. Some became involved in recruiting for seagoing enterprises, but otherwise there was little to do. Clive Phillipps-Wolley died in July 1918, by which time his cherished League had evolved from being, not a branch of the British League, but the Navy League of Canada, proud to be affiliated with the parent League in the Mother Country but with a distinctly different approach than before the war - or so its first president, Montreal's William Gillies Ross, fondly hoped.

Ross, the chairman of the Montreal Harbour Commissioners and fully conversant with the terrible plight of merchant seamen both afloat and ashore, had been involved in trying to alleviate their conditions, at least when in port, by fund-raising to provide amenities for them ashore. His efforts had started in earnest in 1916, and when the full force of unrestricted submarine warfare became felt in early 1917 he decided that the only effective way to help was to re-establish the moribund Navy League, this time with the well being of sailors as the League's first priority. ${ }^{30}$

\footnotetext{
${ }^{28}$ The Colonist and The Daily Times, 29 January to 4 February 1913 - another example of Rüger's "naval theatre."

${ }^{29}$ The Mail \& Empire, Toronto, 19 July 1918, a clipping to be found in Library \& Archives Canada (LAC), RG24, File N.S.1080/206, Vol. 1, disappointingly without comment.

${ }^{30}$ See Keeping Watch, chapter 6.
} 
Canadians flocked to the cause, in numbers unimaginable to the pre-war League, and fundraising efforts on behalf of seafarers brought in about three and a quarter million dollars by the time the tap ran dry in 1919. One result of this was that the League, with its Canada-wide appeal, for the first time was able to establish and maintain a corporate existence, the very thing Wickham and Wolley had tried to do before the war. The Navy League of Canada had come of age. By February 1919 the League's affairs were in sufficient order that its governing body, the Dominion Council, felt able to call an annual general meeting encompassing members from all over Canada. In recognition of Victoria's pre-war dominance, and as a memorial to Wolley, it was held there.

It was a gala occasion, and much was accomplished, including the distribution of much of the funds raised

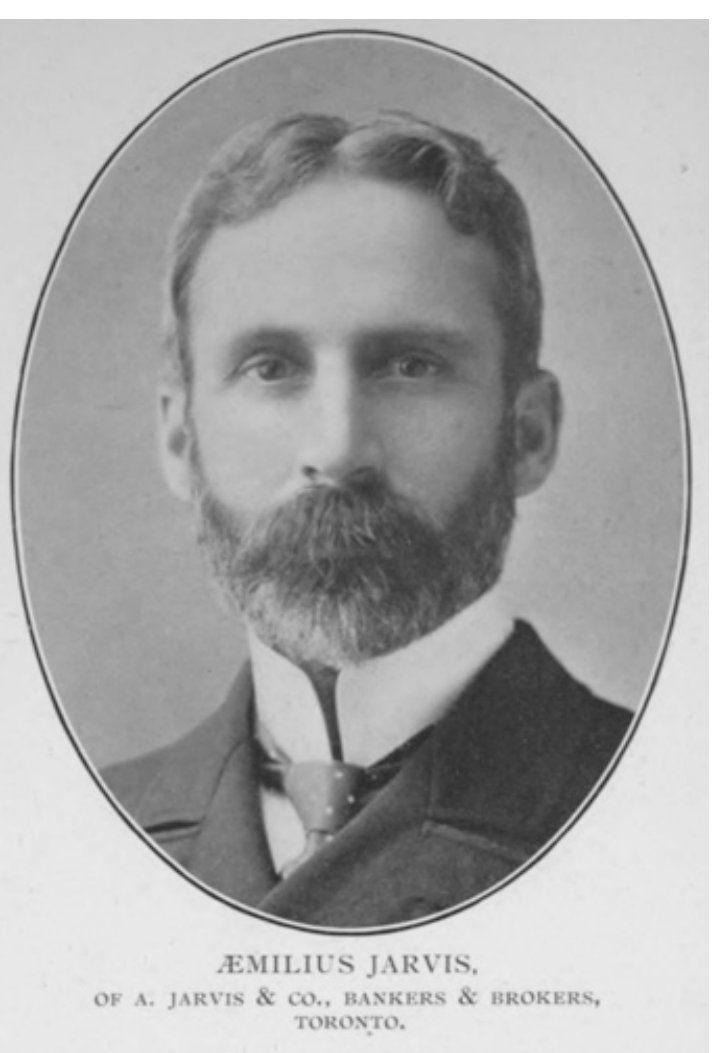

Source: John A. Cooper, ed., Men of Canada: a portrait gallery of men whose energy, ability, enterprise and public spirit are responsible for the advancement of Canada, the premier colony of Great Britain previously, both in Canada and in Britain. But a new focus was quickly in evidence, typified by what became known as the "Victoria Resolution." It was a strong resolution, the core of which stated unequivocally that the "fundamental idea" of Canadian naval policy "should be Empire Naval Defence." Ross, who was being replaced as president by Ontario division's president, Aemilius Jarvis, acknowledged and accepted this shift, and warned that personally he would maintain as his first priority the welfare of merchant seamen, but he then quickly faded from the scene. ${ }^{31}$

Jarvis had forecast his ambitions in advance of the February meeting. In an extensive policy statement dated 1 January 1919 and issued under his name

${ }^{31}$ Navy League of Canada [NLofC] Minutes, February 1919, 87. The two local newspapers had extensive coverage. Emphasis as in original. 
as president of Ontario division, he had listed various "principles" and "policies" for the League. First of the principles was "THAT sea power dominates world action in days of peace as well as in war times." This was to be achieved by a policy of supporting "at the proper time any naval policy that our Government may evolve which is based upon naval strategy as applied to the Empire" by influencing members of Parliament to support a naval policy "so that never again shall this vastly important subject be made a political football. ${ }^{, 32}$ When Jarvis modestly accepted the presidency in Victoria a month later he acknowledged he and Ross had had differences of opinion. ${ }^{33}$ Jarvis, with no known previous connection with the old Navy League, seemed determined to hark back to the policies of Wolley.

Jarvis moved quickly to imprint upon the League his own vision of Canadian naval policy. Admiral Jellicoe called at Canada on the last leg of his empire tour of 1919, and the Navy League president summoned Dominion Council to meet in Ottawa with the admiral during his consultations with the Canadian government. He also scheduled meetings with Prime Minister Borden and his minister of Marine \& Fisheries and the Naval Service, C.C. Ballantyne, in what James Eayrs called "the beginning of a curious non-governmental influence upon (Canadian) naval policy." ${ }^{34}$ While reports from Australia and New Zealand remarked on the positive way in which the Jellicoe mission and its subsequent voluminous reports were received, in Canada it was an entirely different matter. None of Jellicoe's four options for a Canadian naval policy was adopted by the Borden government - even though the Navy League urged the acceptance of at least his minimum recommendation. Nevertheless, leaving Ottawa on 28 November 1919, Jarvis felt sufficiently encouraged to claim to the press that the Navy League of Canada was now the government's "unofficial arm in naval and marine matters."

In fact the government came within a hair of disbanding the RCN in its entirety. Subsequent to Jellicoe's mission, the Canadian government accepted, somewhat gracelessly, one old light cruiser and two destroyers from the British, which thereafter they tried to ignore as far as was possible.

Jarvis persisted in his determination to return to the pre-war days to agitate on behalf of sea power and a Canadian sea consciousness, perhaps not always fruitfully. In a summary of opinion in the country on "Canada and Empire in Navy Question" for the London Times, its Toronto correspondent reported that while "public opinion clearly" favoured a Canadian navy, there was also "apprehension" abroad that this was "stimulated by the activities of the

\footnotetext{
32 Archives of Ontario, Pamphlet 1918, No. 57, "No.1, Policy of the Navy League of Canada," by Aemilius Jarvis, President, Ontario Division, Navy League of Canada, dated 2 January 1919.

${ }^{33}$ NLofC Minutes, 6-8 February 1919, 84-7. The differences of opinion were not minuted.

34 James L. Eayrs, In Defence of Canada, 1: From the Great War to the Great Depression (Toronto, 1964), 157. Contrary to Eayrs' assertion that the Canadian Naval Service retained its wartime aversion to the activities of the Navy League, both Commodore Walter Hose and Ballantyne later paid tribute to its members' efforts and participated in them. See Keeping Watch.
} 
Canadian Navy League;" he credited these misgivings "to the League's Victoria Resolution." ${ }^{35}$ This was an early appreciation of the possible counterproductivity of agitation in the post-war period.

This did not deter Jarvis. With the fate of the navy in the balance he and Dominion Council mounted an aggressive campaign to convince the government to establish a viable naval policy. A coordinated letter-writing blitz was undertaken, to members of Parliament and the cabinet to that effect, starting in early April 1920, at the precise time Ballantyne was re-thinking his earlier, rash determination to do away with the Naval Service entirely. At the League's annual meeting on 2-3 June 1920, its members were told of the massive propaganda effort, and on 14 June Ballantyne announced his about-face in Parliament. When the minutes were finalised for the League's meeting the remark was added that "the result was the introduction of a Naval Policy" for Canada. ${ }^{36}$ It would be a pyrrhic victory.

The one bright spot in the next few months was the arrival in Halifax of the three ships upon which the new Royal Canadian Navy could be built. Effusive greetings were passed to the little fleet's commander from Navy League branches in Toronto, Montreal, Winnipeg, Victoria, Charlottetown and Saint John. The fact that these were hand delivered by Minister Ballantyne augured well for the standing of the League in at least some government circles. Similar celebrations were held in Victoria, and western representatives of the League convened regional meetings in Victoria and Vancouver (to which they were transported in the ships) to try to ensure a western perspective was sent to its Toronto-based headquarters. These meetings in particular were well covered in the local press. ${ }^{37}$

And then came literally a "bolt from the blue." On 1 January 1921 the British Navy League issued what Castell Hopkins in that year's Canadian Annual Review characterised as an acceptance of pacifism and a willingness to move towards disarmament, whilst also conceding "joint guardianship of the Seas" with the United States. Hopkins labelled it "an extraordinary volte-face," and Jarvis moved quickly to dissociate the Canadian Navy League from the document. All members of council were canvassed for their opinions, and were

\footnotetext{
35 Reprinted in The Daily Colonist, 6 April 1920. Eayrs, In Defence of Canada. 161, suggests that by June 1921 Jarvis had changed and realized "a new outlook was required;" perhaps - but his methods remained unchanged.

${ }^{36}$ This episode, where Ballantyne was in effect cut adrift by his cabinet and caucus colleagues, is one of the treasured stories of Canadian naval historians, perhaps none more so than Eayrs, In defence of Canada, 162-5. He cites a cabinet member writing to Borden of these exciting times, and notes in passing the League's messages. Ballantyne dismissed his earlier edict to disband the Navy as simply being a misinterpretation of his plans for a "house cleaning," in order that the Naval Service could retain its best personnel. NLofC Minutes for 1920, 183-4, contain the triumphant remark. Unless Ballantyne papers can be located we can only guess at the validity of this claim.

37 The Halifax Herald, 21 December 1920; The Vancouver Daily Province, 9 March 1921; and The Daily Colonist, 10-30 March 1921.
} 
reported as "practically unanimous" in agreeing that it would in no way change the position of the Canadian League - at least until the pending imperial conference announced its approach to naval defence. ${ }^{38}$

In Halifax on 1 June in his presidential address, Jarvis made a remarkable statement. Denying that the League had been "formed for the purpose of soliciting funds for seamen and seamen's Institutes, or for the relief of seamen's dependents" - it was as well ex-President Ross was not in attendance - he claimed it had been formed "primarily to educate the masses to the vast importance of sea power, sea knowledge, sea interest and how they are irrevocably interlocked with National existence." Not only did he somehow escape unchallenged for this falsity, but he was also able to convince the meeting to pass a resolution to be delivered to the new conservative prime minister, Arthur Meighen, just about to leave for the imperial conference, giving him the League's full support so long as his endeavours maintained "Canada's nationality and Imperial unity in the matters of Imperial defence." The mover of this resolution was Ontario division's new president, Sam Harris. ${ }^{39}$

By the end of 1921 the situation had worsened. The imperial conference had ended inconclusively, awaiting the outcome of the Washington Naval Conference. This was expected to (and eventually did) result in a naval arms limitation treaty - and in October of that year, as navalists anxiously awaited, the British Navy League once again spoke, this time advocating earnestly a switch from the concept of "Sea Power" to one of "Sea Service." This time its executive had gone a step too far. Dissidents within its own organisation denounced the policy as "one of the most grotesque documents ever published," and threw them out of office shortly afterwards. ${ }^{40}$

Jarvis's reaction was no less fierce. Summoning a meeting of likeminded colleagues in Toronto they issued "an eight hundred word manifesto" entitled "The Navy League of Canada and DISARMAMENT." It was a somewhat incoherent document, more remarkable for its anti-American sentiment than anything else. The annual minutes for 1922 recorded that "in taking this step the Navy League of Canada was not only loyal to its motto 'Keep Watch,' but proved itself to be the FIRST NAVY LEAGUE IN THE BRITISH EMPIRE." The manifesto was to have dire consequences, both for Jarvis and for the League. Jarvis was rebuked for failing to consult council

\footnotetext{
38 NLofC Minutes 1921, 254, not a unanimous vote. In the report of Ontario division's annual general meeting in The Globe, 19 May 1921, the headline read "NAVY LEAGUE FACING PUBLIC APATHY." At this meeting a new name emerged: Sam Harris was elected the division's president, replacing Jarvis. Ontario division minutes show the two men had several disagreements prior to this.

${ }^{39}$ NLofC Minutes 1921, 286.

${ }^{40}$ Covered extensively in The Times, 14 October 1921. In the explanation of the executive committee's memorandum its members invoked Joseph Conrad: "it is not the spirit of adventure" that keeps nations on the seas, "but the spirit of service."
} 
before issuing such a document, ${ }^{41}$ and the League lost the support of one of Canada's most influential newspapers, the previously supportive Manitoba Free Press. ${ }^{42}$ Ontario's Sam Harris replaced Jarvis as League president; a man very much after the cast of Wolley and Jarvis, with him at the helm the League's approach to sea power was destined to be set for fourteen years - fourteen years during which the Canadian Naval Service fought desperate battles for its survival, years in which it needed all the support it could get.

Nobody in the League could claim that they had not been warned. Just prior to taking over the League's presidency Harris had told Ontario division that any government plan to do away with the navy would "be opposed to a finish by the Navy League day of Canada. ${ }^{, 43}$ He told the meeting that the day before the prime minister had been handed a letter spelling out the League's approach. ${ }^{43}$ This belligerence - almost electioneering for the council presidency - was toned down somewhat by the time Harris reached Montreal for the annual meeting. Although telling its members the purpose of such meetings was to discuss League policy, he held back from outlining a naval policy then, at least until "the Motherland" had finally decided on its "Navy of the Future." ${ }^{44}$ In reality Harris had much more business at hand, repairing the damage caused by Jarvis and to operate the League, which was bleeding money, "on business principles." 45

As to the League's role as "the only Organisation representative of public opinion in Maritime matters in... Canada," he warned that while its "avowed policy" was to "create an atmosphere favourable to the development of (an) effective naval programme," given the climate in Canada this could only be approached "in a perseverant and consistent way." ${ }^{46} \mathrm{He}$ explained this even further in the following year, telling council that, while the League remained committed to "its original position as to Empire Naval Defence," this was not to be taken to mean that in any way "the League proposes to teach Navalism, or what some term Militarism." "Education is salvation," he stated, "therefore, the Navy League must preach and teach the gospel of Empire security through preparedness, from coast to coast, with tact and courtesy." $" 47$

There were of course lapses in this sane and sober approach. In 1924, in what must possibly have been the last of the great imperial naval impulses, the Empire Tour of the Royal Navy's Special Service Squadron, the ships visited Canadian ports. It was led by the world's largest warship of the time, HMS

\footnotetext{
${ }^{41}$ NLofC, Ontario division minutes, 30 May 1922. This rebuke was not repeated in Dominion Council minutes. As Jarvis had already committed various other sins, his failure to retain his presidency cannot be attributed entirely to this. See Keeping Watch, 159-6.

42 The Manitoba Free Press, 15 December 1921 and 27 February 1922.

43 The Globe, 17 May 1922. The Liberal government of Mackenzie King now ruled in Ottawa, with dire consequences for the Naval Service.

${ }^{44}$ NLofC Minutes 1922, 28, renumbered as of Harris's election.

${ }^{45}$ NLofC Minutes 1923, 50-1, 82.

${ }^{46}$ NLofC Minutes 1923, 82; this was read out in the Ontario division's annual report to council.

${ }^{47}$ NLofC Minutes 1925, 172. See footnote 54.
} 
Hood, escorted by HMS Repulse and assorted cruisers. Harris seized the opportunity to re-schedule the council's annual meeting to coincide with the squadron's call in Victoria. Newspapers were full of the occasion, whether in Victoria and Vancouver, or later when the ships called at Halifax. ${ }^{48}$

Harris basked in the atmosphere, and his own lapse occurred during the visit when he spoke out on the most controversial imperial naval topic of the day - what Britain should do with its naval base at Singapore. Britain had asked Canada for its opinion, which to Harris's horror the Liberal government of Prime Minister William Lyon Mackenzie King had declined to give. At the very least, Harris argued (and the League passed a resolution to that effect), the Canadian government should at least have the courtesy to respond. He then compounded his mis-step by saying that Canada should tell Britain not to abandon its plans for its expansion, which was critical to the safety of the empire. As those opposed to the League's stand did not hesitate to point out, the idea of a navy-less Canada daring to suggest a naval policy to Britain was ludicrous. ${ }^{49}$

The level of consistency in the League's methods of getting its policies accepted is hard to assess, certainly in published sources. Eayrs effectively discounted them after 1919, and the official naval historian also largely ignored them. ${ }^{50}$ Members occasionally burst out in exasperation when they felt that council was being too respectful. The most extreme examples of this came from British Columbia. In February 1925, BC division's W.H. Langley circulated a press release calling for Canada to build "four light cruisers of the latest type for Canada's naval defence" - an effort which Harris later recalled had caused him embarrassment. ${ }^{51}$ The Colonist reported the impressions of Vancouver Island's representative at a recent council meeting: she regretted council had taken "No action whatsoever... upon the important and pressing subject of Canada's place in the naval defence of the Empire and that no indication of any definite policy has therefore been forthcoming as a guide to the supporters of the League

\footnotetext{
${ }^{48}$ An entire book could be written of this, the climax of British sea power extended to the empire. The author holds a full 3-ring binder of the newspaper response to the visit in Australia, Canada and Britain, where it was followed assiduously - and ultimately with great scepticism - by The Times. See especially the editorial on 27 September 1924.

${ }^{49}$ See the reports in The Daily Colonist and Daily Times of Victoria, 23-30 June 1924. Strangely enough, the former was obviously uneasy with the stand, as it barely mentioned it; the latter gently chided him for his presumption. The motivation almost certainly was a result of another initiative taken by Harris at this time, to rekindle cooperative imperial participation in the Navy League movement, a concept effectively destroyed when Frederick Williams Taylor noted geographical conundrums when he spoke in 1931 (see footnote 4 above).

50 Eayrs, In Defence of Canada, and Gilbert N. Tucker in both volumes of The Naval Service of Canada, paid scant attention to League efforts. The League fares better in the updated official history, Johnston et al, The Seabound Coast, passim.

51 The Vancouver Daily Province, 1 February 1925. The headline read "OTTAWA MUST BUILD NAVAL CRAFT." Harris told the British Navy League in 1929 that this "was one of the worst cracks the Navy League had ever had in its consistent work;" The Navy, December 1929.
} 
throughout the Dominion." 52 Sometimes external factors well beyond his control compromised his caution. Thus when the Australian and New Zealand premiers passed through Canada in early-1927 and castigated Canada for its dismal record on naval defence, the consequences affected his efforts. Prime Minister King was not amused, and as a result, as Harris told his London audience in 1929, "the Canadian Government... turned right around and went into Air Force work, where they were not being criticised." 53 This and similar episodes were later remembered by that fount of insider knowledge on RCN matters, J.A.E. Woodhouse, when he wrote that "the Navy's friends in Canada are as dangerous as her opponents," and that "it is necessary to coordinate thought and speech by discouraging ideas of contributions to the Imperial Navy or of immediate and large naval expansion. ${ }^{, 54}$ Seven years later, when Maurice Hankey made his empire tour he expressed similar remarks. ${ }^{55}$

There were also occasions in which Harris did exercise obvious restraint. Thus, when in 1925 retired Admiral of the Fleet Jellicoe virtually demanded that the empire build cruisers to share the imperial naval burden, he was forced to deny his hero - albeit in an obscure newspaper. Interviewed by the Sault Ste Marie Star on 10 December 1925, he let it be known that the Navy League of Canada was "opposed to the Jellicoe Plan of direct assistance by Canada to the Imperial Navy." Thereafter, when Harris did give rein to his own feelings, he did so either in private, at Dominion Council meetings, or in Britain. This was especially evident as the deliberations of the London Naval Conference unfolded, with its concentration on naval arms limitation. ${ }^{56}$

The lowest point of this tactic of respect occurred in 1931 - and again involved Jellicoe. The admiral had come to Canada for another purpose, and was requested to open that year's Canadian National Exhibition in Toronto. Harris was the president of that august body that year, and tried unsuccessfully

52 The Daily Colonist, 21 October 1927. The League, bless its heart, had been open to female members in their own right from the beginning. Although it did not elect its first lady member until after 1965, members of the I0DE were ex officio members at branch, division and council levels.

${ }_{53}$ Keeping Watch, 219-20.

54 Pay Cdr J.A.E. Woodhouse was the RCN's Naval Secretary from 1922 until 1927; he left typed memoirs that now reside in the archives of the Directorate of History \& Heritage (DHH), Ottawa, File 8.1/520/1440 5, Vol. 9, "RCN History (General) 1920-1930. The naval "story" that Woodhouse espoused in his memoir could very well have been plagiarized from League sources, it was so similar.

${ }_{55}$ Maurice Hankey, secret report, "Impressions of Canada, 1934," cited in J.L. Granatstein, "The Man of Secrets in Canada, 1934," The Dalhousie Review 51:4 (1971), 505. The remarks Hankey noted as being distasteful to Canadians were by Admiral Keyes and Lord Lothian. When Keyes made his speech at the Empire Club in Ottawa, both Harris and Jarvis were head table guests. Newspaper reports on this event at least were unexceptionable. Hankey might just have been predisposed to be critical of Canada at the best of times. Australian born, he was critical of Canada's foot-dragging in the matter of naval forces.

${ }_{56}$ See the Harris interview with The Bystander [n.d.], cited in The Vancouver Daily Province, 30 March 1930. In this interview Harris revived his previous anti-Americanism, thus following in Jarvis's steps. 
to muster Dominion Council to attend the Navy League banquet accorded the "Hero of Jutland." The Globe chose this time to proclaim itself as captivated by Jellicoe, reported that the only real "tang of the sea" occurred at the banquet and then had nothing else to say about Navy League efforts. Instead it praised Jellicoe's message in consecutive editorials on 4 and 5 September 1931. The admiral had pointed out that Britain was not living up even to the low standards of naval force allowed under the London Treaty, particularly in the production of destroyers. In "The Jellicoe Warning," The Globe's editor chastised Canada for its "presumption" in expressing "opinions on British naval policies" when the country's "own contribution to the cost of common naval defence is virtually nothing." He warned that the day might come "when Canada will have to choose between paying for naval protection or being deprived of it." ${ }^{, 57}$ The implication was that Canada could take up the slack in the destroyer shortage but still the Navy League kept silent. Harris remained respectful.

At annual meetings of council, Harris's presidential addresses were politely listened to, and as likely or not accorded only a few lines in the minutes. An extreme example was that for 1932, where in three and a half lines it was recorded that "Mr. Harris drew attention to world conditions and the work of the Navy League in relation thereto. The Address was listened to with earnest attention and warmly received." ${ }^{58}$ There was no mention of naval matters in the longer report of his 1933 address, nor were there any resolutions on naval matters. Not until 1934 was there a glimmer of hope to be found in the minutes. Then, however, he told council that the League was coming in from the cold, that he believed "the Navy League, in the not too distant future, will be called upon to be a rallying point for Naval and Mercantile Units." He asked council to pass a "strong resolution" to send to the government regarding Canada's naval service. Whether or not he considered the one that passed as sufficient is not recorded. It was nothing if not respectful, simply calling "the attention of the Federal Government to the question of reasonable defence for the sea borne and coastal trade of Canada, and... to take steps to increase the naval forces of Canada." 59

By this time neither scaremongering nor agitation was necessary. If the Aga Khan, ${ }^{60}$ Ramsay MacDonald, ${ }^{61}$ and especially William Lyon Mackenzie

\footnotetext{
57 The Globe, 5 September 1931. The editorial the day before endorsed Jellicoe's challenge to the empire to make up Britain's deficiency in the production of destroyers, and pointed out this was within Canada's capacity to do. Harris in fact told the British Navy League during his revelation of his tactics in 1929 that the Navy League of Canada had been instrumental in getting Canada's destroyer production started.

${ }_{58}$ NLofC Minutes, 1932, 486.

59 NLofC Minutes, 1934, 577 and 592-3.

60 The Aga Khan was quoted in The Times, 24 October 1934, as making no apologies at a Navy League Trafalgar Day celebration for his full support for "adequate financial provision... for naval security." This was after his appearance at the Disarmament Conference in Geneva.

${ }^{61}$ British Prime Minister Ramsay MacDonald, a Labourite and staunch pacifist, was forced to change his mind at this time. See the editorial "MacDonald Stands for an Armed Empire Now," in
} 
King, had all become convinced that preparedness and rearmament had finally become necessary, then it was going to happen. All of a sudden, Harris and the Navy League were preaching to the converted. While most would credit Adolf Hitler for this change, and Marc Milner, perhaps tongue in cheek, credited Mackenzie King's grandfather from on high for the prime minister's conversion, ${ }^{62}$ Sam Harris had no doubts. He triumphantly told his members at their annual meeting in 1935 that it had happened as a result of the Navy League's "consistent yet respectful campaign." Having refrained from propounding any naval policy, the restraint had finally borne fruit. He reminded them of the Victoria Resolution of 1919 and its bold statement that "The FUNDAMENTAL idea of the Navy League being Empire Defence" and that "that policy has never been changed." It was time to turn members' attention from Sea Cadet matters and espouse fully the concept of "SEA POWER." That his colleagues were still not wholly convinced was shown by the sea power resolution then passed - identical to that of the previous year. ${ }^{63}$

The following year was not a good one for the Navy League. Both Admirals Jellicoe and Beatty had died since 1935, and the League itself had grown weary of Sam Harris. He had been replaced as president of Ontario division in 1935, and the new divisional president, John Goodwin, came to the 1936 council meeting to do battle with Harris. Mostly to do with the dreadful state of League finances - Harris had been unable to enforce business principles, and Ontario division had, until 1934, made up for any financial shortfalls - Goodwin also had his eyes on a larger target: naval policy. In a fully paid advertisement in Toronto newspapers in early March 1936, he threw down the gauntlet as the advocate of naval power and the keeper of Canada's heritage.

As the Ontario presidency had been for the past two council presidents the launching point for national office, Harris could not let this go unchallenged. Telling Goodwin that the advertisement, "while timely and very good," contravened League policies, as the expenditure on it had been made "without the recommendation of the Finance Committee and approval of the Executive," he accepted Goodwin's resignation from council's advisory committee ${ }^{64}$ Goodwin never became League president - but neither did Harris retain that position. Instead he was replaced by a caretaker president, a reality that extended for two years, until the eve of the war. In this hiatus, sea power and naval policy was never mentioned in League minutes, although in 1937 Harris was able to get passed a resolution praising the government for increased appropriations "for the Royal Canadian Navy. ${ }^{65}$

Canada did enter the Second World War with the nucleus of the sort of

The Montreal Daily Star, 22 December 1934.

${ }_{62}$ Milner, Canada's Navy, 69-70.

${ }^{63}$ NLofC Minutes 1935, 604-5 and 622. Emphasis as in original.

${ }^{64}$ NLofC Minutes, 1936, 11. This came after the reading of a series of rancorous letters between Harris and Goodwin.

${ }^{65}$ NLofC Minutes, 1938, 62. 
Navy with - and with which the war at sea would be fought. Respectful had verged on the sycophantic, and whatever educational programme had been carried out had been mostly out of the hearing of the general public. Agitation had long since been discarded as a viable tactic for the Navy League of Canada, and it is debatable if the League's efforts had counted for very much. Whether in the final analysis it could have speeded up the development of Canada's navy, especially when faced with King's Liberal government, is questionable. All that can be said is that no charge of scaremongering could be laid at the doorstep of the Navy League of Canada. 